\title{
READING THEYYAM AS AN ARCHIVE OF THE SUBALTERN COMMUNITY OF NORTHERN KERALA
}

\author{
Divya M Menon ${ }^{1} \rrbracket$, Sreejith $D^{2} \square$ \\ MPhil Scholar at CHRIST (Deemed to be University), Bengaluru, India \\ Assistant Professor at CHRIST (Deemed to be University), Bengaluru, India
}

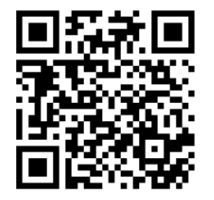

\section{ABSTRACT}

Theyyam is a ritual art form exclusive to Northern Kerala, performed by the Scheduled Castes \& Scheduled Tribes. It is the socio-religious movements that gave them a platform to put forth their problems and change the attitude and treatment of upper castes towards them. Until then, it was a medium for them to present the trauma and victimhood long endured by their community under casteism. This is well fabricated in various elements surrounding Theyyam, such as Thottam Pattu. Theyyam also projects the kinds of ritual and spiritual practices of their community. So, this research attempts to read Theyyam as an archive of the subaltern community by borrowing the Archive concept defined by Gayatri Chakravorty Spivak in her essay 'The Rani of Sirmur: An Essay in Reading the Archives.' As the art form is linked with religious beliefs, it has survived over the years, recognising the community's struggles under casteism and their heroic figures. Thus, this research also attempts to have a close reading of each element surrounding it.

Received 01 September 2021

Accepted 10 October 2021

Published 08 November 2021

\section{CorrespondingAuthor}

Divya M Menon, divyammenon11@gmail.com

\section{DOI}

\subsection{1/shodhkosh.v2.i2.2021.41}

Funding: This research received no specific grant from any funding agency in the public, commercial, or not-for-profit sectors.

Copyright: (C) 2021 The Author(s). This is an open access article distributed under the terms of the Creative Commons Attribution License, which permits unrestricted use, distribution, and reproduction in any medium, provided the original author and source are credited.

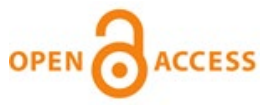

Keywords: Theyyam, Medium, Archive, Religious Beliefs, Struggles, Casteism

\section{INTRODUCTION}

Theyyam is a sacred ritual performance exclusive to Northern Kerala, performed by the Scheduled Castes such as Cheruma, Pulaya, Velan, Malayan, Anjoottan, Munnottan, and Mannan/Vannan and Scheduled Tribes such as Mavilan, Kurichiar, Karimbalan, Kalanadi, Vettuvan, Malavettuvan. It is one of the oldest art forms in Kerala. It consists of thousands of year-old rituals and traditions and is mainly performed by male members of those communities except Devakoothu ${ }^{1}$ performed by women belonging to the Malayan caste. There are about 300 varieties, and each one is different from another, and so is the stories narrated. The kind of Theyyam performed will be based on the deity of the temple. Being a combination of dance, music, dialogues, and oracles, healing has attracted people from various parts of the country and abroad. The performances are held at sacred places such as Kaavu, Mundya ${ }^{2}$ or Kulam ${ }^{3}$ It is placed among the ritual art forms of Kerala, conducted for various motives such as attaining prosperity, pleasing Gods, eliminating diseases and evil possessions, etc. Apart from being a ritual art form, it also provides the historical records of the struggle and their protest to the problems they faced from the upper castes under casteism. The place of worship to the performer's costumes shows how much the art form is bounded with their community's cultural and spiritual practices. And these rituals are in practice from the olden times. It can be understood from the kind of pooja's \& sacrifices done during the performance. Moreover, through Thottam pattu, they convey the great deeds of the people from their community. All these things can be traced from 
its origin and through various things surrounding it, and so the art form projects its linkage with the community. Markose, B (n. d.)

Thus, this research attempts to read Theyyam as an archive of the subaltern community by dragging in the concept of archives mentioned by the Indian scholar and feminist critic Gayatri Chakravorty Spivak from her essay 'The Rani of Sirmur: An Essay in Reading the Archives.' Spivak has done literary analysis of British records to demonstrate the inseparable of language from the colonial/imperial project's goal of world domination. To substantiate the arguments, she drags in the threat of a Himalayan queen (Rani) to 'become sati' (That is, to immolate herself). It is interpreted as the plight of subalterns of 'third world women' in particular. Almost all dictionaries define an Archive as a collection of historical records or documents that provides information about an institution, place, or group of people. While Spivak is of the notion that it is the 19th-century European historiography that defined archives as a repository of facts that is they are constructing a fiction whose task is to produce a collection of the 'effects of the real' and a 'misreading' of it produces a proper name of the thing which is archived. An archive can be considered a literal substitute for the past, which is already lost for the historian. When it is fetishized, it becomes the repository of past traces and might be reconstructed. Thereby it creates a mystifying experience, and it becomes subject to question. There might be things that are excluded and included in constructing an archive. The things included in making an archive is dependent on the historian's genealogy; that is, it might be because of the intellectual power of the historian. It can also be due to the lack of evidence that the historian gets on a matter, or it can be from the historian's analogy that certain matters are excluded. Markose and Thomas (2018)

\subsection{POST OCCUPANCY EVALUATION (POE)}

\subsubsection{FINDINGS AND DISCUSSION}

\section{Origin of Theyyam}

The pioneer research scholars in Theyyam, K.K.N Kurup, and S. Settar traced the origin from the Sangam period (300 BC-AD 250) and Velan Veryadal (Marks the beginning of the dance tradition in Tamizhakam ${ }^{4}$ ) in the 5th century. Later, the earliest form of Theyyam went through many transformations as it got intertwined, overlapped, and even superimposed by other traditions and spiritual expressions of people in those times. In the Sangam period, the southern states were not divided as in the 21st century. It extended from Venkatam (Andhra Pradesh) in the North to Kanyakumari (Tamil Nadu) in the South and was known as Tamizhakam ${ }^{4}$ The art form took the form of Bhuta worship in the Upper North - Tulunad and South Canara (At present in Karnataka) and in the South region, which comprises South of Korappuzha (At present Kozhikode \& Malappuram districts of Kerala), and they called the art form as Thira. In Kolathunadu (At present, Kannur \& Kasaragod districts of Kerala), the art form is known as Theyyam. Thus, these art forms share lots of similarities in common, from costumes to music etc. Not just that, there is an exchange of characters portrayed in these art forms. That is, such as Perumpuzha Achan, are related to the people \& places of Tulunadu, and vice versa, Theyyam such as Malaya Chamundi and Bappiriyan from Kerala has become part of Bhuta worship. Bhuta worship is also practised by Scheduled Castes such as Nalke, Panara, Koppala, Parava, Pambada, etc. Bhuta cult, or the worship of the divine spirits through art forms, is believed to be one of the ancient religious faiths of South India. Even at the present times also these art forms are preserved and practised with their whole aura. Moi (1989) 
In Tamil literature, there is a description of the five different habitats of the Sangam period. When one tribal group enters the ecosystem of a particular thing, they change the traditional occupation to adapt to the new ecosystem. Thereby, it forms a new ecosystem based on the occupation, and even the deities worshipped by these tribal groups also transform. In the Sangam period, the worshipping of trees, animals and stones etc. were highly prevalent. Thus, later they included the worship of dreadful forms of nature and even the dead heroes. This animist mode of worship was highly influential on their religious beliefs. All these kinds of practices show the kind of relationship man had with nature. Through this animist mode of worship, they spiritually connected themselves with trees, animals etc. Furthermore, later the religious institutions and certain trees were associated with the worship of particular gods.

This mode of worship is well reflected in Theyyam, as it also worships ancestors and nature. This itself shows that the tribal communities in Kerala still carries the earlier forms of religious beliefs and practices. Dr Raghavan Payyanad, a notable research scholar on Theyyam, mentions that "Theyyam should have been a primitive form of ritual dance. The transformations in the social structure, cultural transformations, were well reflected in it. At one point of time, everyone should have participated in the ritual dance. Today a section of people performs it with the support of all others for the wellbeing of one and all." (Payyanad, Folklorinu Oru Padhanapadhati). With the evolution of time, a transition has happened from worshipping the deities under the trees to worshipping them inside a permanent well-constructed building called temples.

Further evidence can be traced from the human-like engraving of Edakkal caves in Wayanad, which projects the practices held during the earlier phases of human life in that area. According to writer Panchanan Mitran, these engravings date back to B.C.1000 and B.C.700. While a research scholar Iravatham Mahadevan is of the argument that it must have been done around 5000B.C. Some of the paintings and petroglyphs highlight pre-historic elephants, various tools, and tribal chieftains. The cravings of humans, animal-like figures, symbols convey people's spirituality in the pre-historic era. Apart from that, there are various kinds of engravings on the rock. It is considered to be from the pre-literate, megalithic period to the literate, postiron Middle Ages. Some of the engravings convey the hunting and food gathering systems. There are some engravings of human figures with men dancing in a headdress, conveying the ancient devil dance. It is highly similar to the costumes of Theyyam, and it is considered to be the beginning phase of Theyyam. It is believed that the tribal communities of those times used these kinds of rituals to convey their spirituality with natural and supernatural things surrounding them. Payyanad (1998)

The worship of the spirits can be traced from the Pre-Aryan era, and it is considered indigenous to Indian culture. Writer Upadhyaya defines it as "Among the religious faiths of the Dravidians of South India, the spirit cult or worship of semidivine spirits appear to be the most primitive one." (Upadhyaya, "Renaissance in Tulu Literature"). Even now also the tribal communities worship their ancestors on specific occasions through various kinds of performances. These practices are done on the belief that their presence and blessings will help them to attain prosperity. Apart from that, they believed in the presence of their ancestors in forests, hills, trees etc., and they worshipped them through various ritualistic practices. While some of these practices are going on, at certain times, one of the people gathered there would be possessed by the spirits, and they even worshipped them. These kinds of spirit cults are practised in Tamil Nadu, Kerala and Tulunad. The worship 
of the serpent was also common in those days, especially by the upper castes such as Nairs, Namboothiris of Kerala, and they worshipped them in a different place within the compounds of their house. Even today, these practices are also followed in specific households and some temples. They are worshipped in separate places within the temple premises. Serpent pantheons are represented in Theyyam, and some of them are Naga Kali, Naga Bhagavathi, and Naga Rajavu. Apart from that Tiger is another animal that is worshipped through Theyyam. This practice was introduced as in those times the tribal communities were terrified of tigers as they destroyed the paddy fields and attacked people and so by pleasing them, they can save themselves from their attacks. Theyyam such as Puliyanoor Kali, Puli Maran, and Puliyoor Kandan are some examples of it.

Ancestral worship is done based on the belief that they can influence the fortune of the present and future generations. Generally, the worships for them are done on new moon day on a specific month and sometimes, when the rituals are going on, the spirits of the ancestors will possess some people. Certain Theyyam, such as Achan, Dharma, Karnavar, Thondachan, etc., is performed to attain peace for the ancestral spirits. They worshipped Earth as female energy during those times, and it was seen as the principal deity. This was continued in the times of Aryans, and the Gramadevathas ${ }^{5}$ worshipped by the Dravidians were transformed into kshetradevathas 6 whom the Aryans worshipped. Theyyam such as Rakta Chamundi, Vira Chamundi, Madayil Chamundi etc. represents those pantheons.

Later in the land-owning system \& plough agriculture introduced by the Kerala Brahmins is based on the caste hierarchy (Chaturvarna), also known as Avakasham. Furthermore, if the people deviated from the established laws, they were punished by the upper castes. Under the new law, the right to perform Theyyam was given to the Dalits. As they belonged to the lower strata in the Chaturvarna, their voices were suppressed by the upper castes. In these times, the cultural and religious beliefs of the dominant classes became strong. However, the Dalit communities strongly followed their religious beliefs. So Theyyam underwent many changes in indigenous communities, who were later categorised as Scheduled Castes and Scheduled Tribes. Theyyam is also known as Theyyattom, Kaliyattom, Thira, Thirayattom, Kolam, Kolamkettal, etc. Certain Theyyam is performed by artists belonging to certain castes. For example, Pottan Theyyam is always performed by the Malaya community. Thus, it gave the Dalit communities of Kerala a platform to put forth their problems. That is the main reason the heroic figures represented in Theyyam are from their communities. Spivak (2021)

\section{Analysis of Various Things Surrounding Theyyam}

\section{Sacred Groves}

Theyyam performances often take place at Kaavu, and it is very much different from the mainstream temples. Kaavu, or the sacred grove, is a piece of garden or forest land dedicated exclusively to a particular deity and is guarded over the years in their interests. The statue of the deity is worshipped inside the temple or shrine. Along with the worship of the deity, certain plants, and herbs, such as the Banyan tree, Tulsi, etc., surrounding the Kaavu also get protected over the years.

As different Kaavu have different deities, so their personal needs are also different. Based on that, different kaavu have different kinds of ceremonies and poojas for worshipping them. In Kaavu, Vedic deities are not worshipped, but the indigenous deities such as Goddess Durga, Vishnumoorthy, Bhagavathy, Nagaraja (Serpent King), Chithrakoodam, Yakshi, and Muthappan, etc. are worshipped. The 
tradition of conserving nature can be traced from Pre-Vedic times in India. The earliest food gathering people also worshipped nature, as their livelihood was utterly dependent on it. Thus, Kaavu can be seen as a Pre-Vedic tradition moulded into a new form of worship. This is well reflected in the subaltern practice and also in Theyyam. Even the eco-scientists have always acknowledged the practice of kaavu in the 21st century, where there are many environmental issues like deforestation and global warming, etc. Furthermore, it would be a kind solution for it.

Byju Markose, a notable research scholar in his book Rhizomatic Reflections: Discourse on Religion and Theology, mentioned the embodiment of subaltern religious sensibility within the tradition of sacred groves. "Sacred groves are the embodiment of subaltern religiosity in India. They are the centres of folklore, beliefs and taboos" (Markose 84). According to Byju, tree lore is a vital aspect of the religiosity of the subaltern community as the concept of 'Tree of life' was popular among the subaltern groups of India. He also states that the subaltern community sees their religious beliefs as highly linked with sacred forests. This can also be interpreted as their rebellion against the Hindu fundamentalist movement, which aims to combine the subaltern religious beliefs into the dominant religious beliefs of Hinduism. So, the tradition of sacred groves can be understood as a subaltern effort of eco-restoration.

In the Hindu religion, subaltern religious beliefs and practices were not recognised in homogenisation supervised by Brahmanical cultural hegemony because of the homogenising tendency. Subaltern eco-ethnicities are a powerful attempt that challenges modern religious practices. It is an attempt to bring new theories on religion and ecological restoration to the forefront. (Markose, 91) "According to subaltern spiritual practice, the sacred is housed in the earth, the sky and the whole universe. There is no separatism in this subaltern consciousness, and this consciousness of wholeness dismantles modern dualistic notions of sacred and profane, nature and culture, man and woman, civilised and savage, etc." (Markose 94).

The subaltern religious beliefs are highly linked with ecology, and it is visible in their lifestyles and culture. Sacred groves can be seen as a minor form of the geographical living practices of subaltern communities, mainly the tribal culture. The ritualistic practices in sacred groves can be considered as a rebellion against Brahmanical ritual practices. The subaltern community maintains their religious and cultural practices through sacred groves even in this developing world. This is well acknowledged by Nobel Prize winner for peace in 2004 Wangari Maathai that the different ways of ecological restoration can be interpreted as people's struggle for survival. So along with the religious beliefs, Kaavu gives folklorist, ecological and historical dimensions as well. Upadhyaya (1996)

\section{Thottam Pattu}

Thottam Pattu is a vocal ballad sung before the Theyyam performance, and it lasts for about 20 to 30 minutes, while for some deities, it lasts for about 6 to 7 hours. Thottam is derived from Thottuka, which means creating, making, or feeling, while some argue it is derived from Sthotram, which means a song in praise of the deity. There are about hundreds of Thottam, and each one is different from the other. However, there are similarities between certain Thottam. It is believed that soon after it, the performer will be possessed by divine spirits, and then he is accompanied by 2 or 3 members to safeguard him. They narrate the stories of 
legends from the subaltern community related to the temple's deity, where the performance takes place. Chenda and Thudi are played along with the song. Depending on the time at which Thottam is sung, it is called by different names. For example, the Thottam sung at noon is Uchchathottam and at dusk as Anthi Thottam, etc.

Different kinds of Theyyam will have different kinds of Thottam Pattu. It conveys historical and sociological perspectives as they talk about people's cultural life, practices, and beliefs at that time. Thottam Pattu conveys caste discrimination, slavery, and the ideological differences between upper and lower castes. While some convey the birth of the deity, childhood, and youth of it, and some other kinds of Thottam give descriptions of the qualities and physical appearance of the deity. Some of them have some passages in the native language of North Malabar and the rest in Sanskritised Malayalam. It is considered an attempt at Sanskritization and homogenises the cultural difference between the indigenous forms of worship and the Vedic deities. This was done to legitimise the greatness of the indigenous and powerful deities worshipped in kaavu, as Aryan Gods are always considered superior. Thottam includes Varavili (Invocation), Stuthi (A song that extolls the deity), and Sancharam (Narrates the way through which the deity has arrived at that shrine).

Thottam Pattu also conveys the social scenario of the North Malabar when untouchability was rigorously practised under casteism, and the role played by Theyyam. It also narrates the great deeds of the men from the subaltern community, caste oppression, and gender discrimination. Thottam Pattu of Pottan Theyyam and Vishnumoorthy Theyyam mainly deals with caste oppression. The rituals and practices of Theyyam are almost like the rituals and customs of the tribal community. Its rhythm can be related to some of the tribal performances in Kerala, such as Paliyanritham and Irulanritham.

\section{Sacrifice of Animals \& Pooja's Performed}

Different kinds of Pooja's and animal sacrifices are made for different deities. Based on the deity's appearance and character, Kaavu is classified into Shaivite, Vaishnavite, serpent, human variety, etc. Some of the deities are wild and terrific, so they thirst for animal blood. Goddesses like Kali, Bhagavathi and Chamundi, etc., are manifestations of Sakthi or superpower, while gods like Bhiravan, Vishnumoorthy, Gulikan, and Pottan, etc. represent the concepts of Vaishnavite and Shaivite. Animal spirits are represented through Hanuman, Bali, and Puli, etc.

Blood sacrifices are made for the deities like Kuttichathan, Karim Chamundi and Gulikan. As it can calm down the vigorous form of deity, it was highly prevalent among the indigenous people of Northern Kerala even before the advent of Aryans. With the arrival of Aryans to Northern Kerala, they treated blood sacrifice as inferior and, according to them, it is practised for Non-Sanskrit Gods. Thus, the indigenous deities worshipped by the village people were Non -Sanskrit Gods, and they were considered inferior to the Sanskrit Gods. The binary of Sanskrit Gods and NonSanskrit Gods created many discourses. So later, there was an appropriation of the Non-Sanskrit Gods with Sanskrit Gods by giving them the name of Sanskrit Gods without merging the functions. 


\section{Interpretation of Makeup \& Costumes}

Theyyam is also one of the most visible and spectacular art forms in Kerala, along with Kathakali, Koodiyattam, Ottamthullal, etc. Most of the necessary items used for makeup are taken from nature. The makeup and dressing up for Theyyam is a long process. The makeup starts with Theyyamkeeyal ${ }^{7}$ where the Theyyakaran ${ }^{8}$ (Theyyam performer) wears the Mudi.

Generally, the colours used for Mukhamezhuthu (Facial makeup) are white, red, yellow, and green, and these colours convey various aspects. It helps in the strong projection of Theyyam spirits, and thereby it helps to grab off the attention of spectators. The red symbolises love, violence, bravery, and yellow denotes sickness, ripeness, and death. Black stands for mourning, green shows innocence and eternity, and green conveys a new life beginning. Furthermore, these bright colours are often associated with lower castes in India. These makeups and the costumes compliment the performer on conveying the various Bhava or emotions of the spirit effectively when the spirits possess the performer. Through which an intensifying performance takes place.

Some of the plants used for makeup purposes are having medical importance. Along with the worship of Theyyam, these plants also get conserved over the years. Plants such as Alstonia scholaris, Michelia cempaka, Azadirachta indica, Cocos nucifera, Mimusops elengi, Ixora coccinea, Curcuma longa, and Ocimum sanctum are used for makeup. Among them, Alstonia scholaris, Michelia cempaka, Azadirachta indica, Cocos nucifera, Mimusops elengi, Ixora coccinea are common remedies of some diseases like cholera, eye diseases, and fever.

\section{Role of Women}

As Theyyam is always performed by men when coming to the representation of women, it can be seen as an appropriation of women's voices. In the feudal times in Kerala, men occupied the centre of social, cultural, and political discourses, and women were entirely marginalised. This is well seen in Theyyam, as it is mainly dominated by men even though goddesses outnumber God's pantheon. Women's role is limited to the singing of Thottam except for Devakoothu ${ }^{1}$ as women perform it. Furthermore, when women became victims of patriarchal morality, their voices in Theyyam were mediated through men's (mis)interpretation and are often silenced. Certain Theyyam narrates the stories of lower caste female victims of casteism.

Theyyam such as Kadangottu Makkam, Thottumkara Bhagavathy and Muchilottu Bhagavathy depict gender violence while Neeliyar Bhagavathy projects caste-based gender violence. The myth of victimisation of a young beautiful lowercaste girl named Neeli for her chastity is projected through Neeliyar Bhagavathi Theyyam. In feudal times lower caste women were exploited by upper-caste men. Neeli was also tried to seduce by an upper-caste person, but Neeli threatened him by saying that she would kill him if he touched her. It led to the arousal of a manly ego in him, so he created a fake story of the illegitimate sexual relationship of Neeli with another man. According to the social norms of the society at that time, they decided to decapitate her by her father. On the decapitation day, the separated head rose into the sky, and it was seen as a Godly power. Thus, from that day onwards, Neeli is worshipped as Neeliyar Bhagavathy in Kaavu and through Theyyam. 
While the womanly figures represented in Kadangottu Makkam and Muchilottu Bhagavathi Theyyam experienced verbal abuse, they had to suppress it for the sake of their family and the class and social class norms. The Brahmin women represented in Muchilottu Bhagavathy Theyyam were highly learned, intelligent and chaste. The men in their community had envy towards her, and they were reluctant to accept her knowledge and individuality. So, they invited her for a talk to test her knowledge. She answered all the questions, but the men's ego did not want her victory over them, so they asked her to talk about the most enjoyable and agonising experience in a crooked way. For that question, she answered sexual experience and labour pain. The gathered men for the talk came up with false allegations of the woman being adulterous, as a chaste woman can never speak about sexuality. Therefore, she wanted to prove herself by setting fire on herself. For this purpose, she asked a Vaniyan to pour some oil on her and fire it, and the next day, the Vaniyan happened to see her in the form of Bhagavathy in his open well. From that day onwards, she is worshipped as Muchilottu Bhagavathy and as Kuladaivom ${ }^{9}$ of the Vaniyan community.

Thottumkara Bhagavathi Theyyam is an instance of brutality women face for not affirming women's ideal image as sensitive and emotional created by the patriarchal society. As the woman did not cry on the death of her child, and so she was punished by putting a firepot on the head leading to her death. The Hindu forms of Theyyam conveyed the stories of violence, and the Theyyam created by Muslims known as Mapilla Theyyam also projected the same. A kind of Mapilla Theyyam called Ummachi Theyyam, usually performed in Mekkattillam Kshetram (Temple in Neeleswaram, Kerala), portrays a poor woman from the Muslim religion who had to work in a Hindu royal household under poverty. When she was husking the paddy, an upper-caste warrior happened to see her and verbally abused her for polluting the rice to be served for the deity. Out of the verbal argument, the man got angry and beat her with a stick, which led to her death. From then, she was made Daivakkaru ${ }^{10}$.

All these Theyyam emphasise that men were the centre of knowledge production during the feudal times, and with their power, they silenced the women, mainly lower caste women. Even though Theyyam projected oppressed women's stories, they were all by mediated men's interpretations. They were either killed, accused, or tortured in the name of chastity, and when the acquisitions were proved wrong, they were made as goddesses. At this point, Toril Moi's observation becomes valid "Throughout the history, women were constructed as man's other, denied the right to her own subjectivity and responsibility for her own actions." This again highlights the fact that the individuality and identity of the women were associated with the notions of chastity.

However, Poomatha Ponnamma's story is not even presented in any of the Theyyam. She refused to meet the sexual demands of an upper-caste lord even though he offered her a considerable quantity of rice to meet her hunger out of poverty. Out of the manly ego, he persuaded another Pulaya woman to spread a false gossip that the former had an illicit sexual relationship with some man. At first, she was reluctant but later agreed. When the villagers came to know about it according to the social norms of that time, they decided to burn her alive. While she was burnt alive, she mockingly invited the lord to have a sexual union in front of the villagers. She is not even treated as Theyyam pantheon, but this story is narrated through Thottam in print format. One reason for the absence of this story in Theyyam is that maybe they do not want this gruesome incident to be retold through Theyyam. This can be related to the arguments of Spivak in the essay 'Can the subaltern speak' that when the dominant classes represent the marginalised, they always ensure that 
their interests are preserved. When the men presented the stories of women through Theyyam, they suppressed the female voices and only depicted women's stories that conform to the patriarchal discourse. This is well reflected in the forms mentioned above of Theyyam. Even though women perform Devakoothu ${ }^{1}$ they narrated the stories taken from epics, and they do not present the problems of violence that women had to face. This conveys that the actual voices of women are entirely excluded in Theyyam.

\section{OBSERVATIONS AND CONCLUSION}

As in feudal times, men were the centre of knowledge production and presented things from their viewpoints. Reading Theyyam as an archive of the subaltern community puts forth culture and traditions, but it completely ignored women's actual voices and stories from their community. The art form is highly linked with religious beliefs, has survived over the years, and is giving recognition to the heroic characters presented through it. Apart from that, it is also a way to preserve their culture and traditions. There is no clear evidence that divinities attached with each heroic character in the stories presented through Theyyam are true. However, they have presented the stories of people from their community who resisted the various forms of violence from the upper castes. They are heroes for them and can almost be equated with God. Through Thottam Pattu, they presented their problems to society in general. Theyyam archives every religious and spiritual aspect surrounding their community, along with it also shows how the people have protested against the violence under casteism. With exclusions and inclusions, Theyyam archives the subaltern community in Northern Kerala.

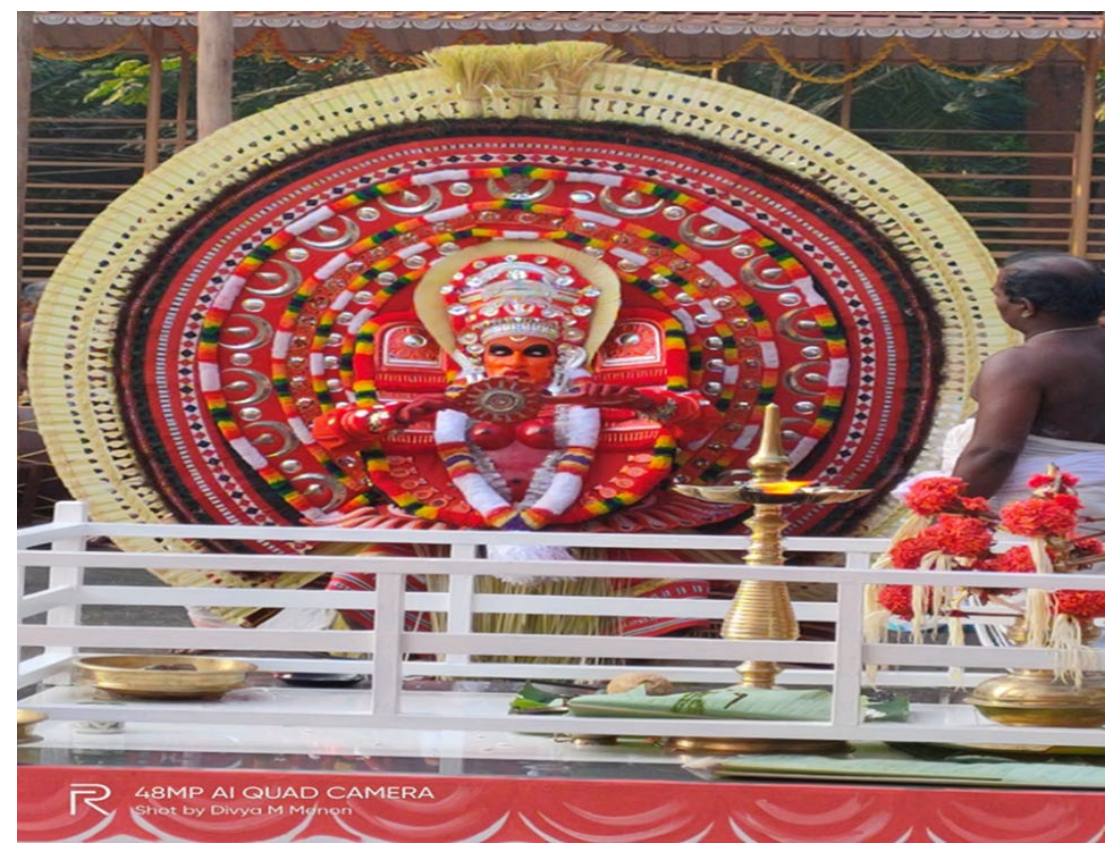

Figure 1 Madayil Chamundi Theyyam looking at the Vaalkannadi (Traditional mirror of Kerala) 


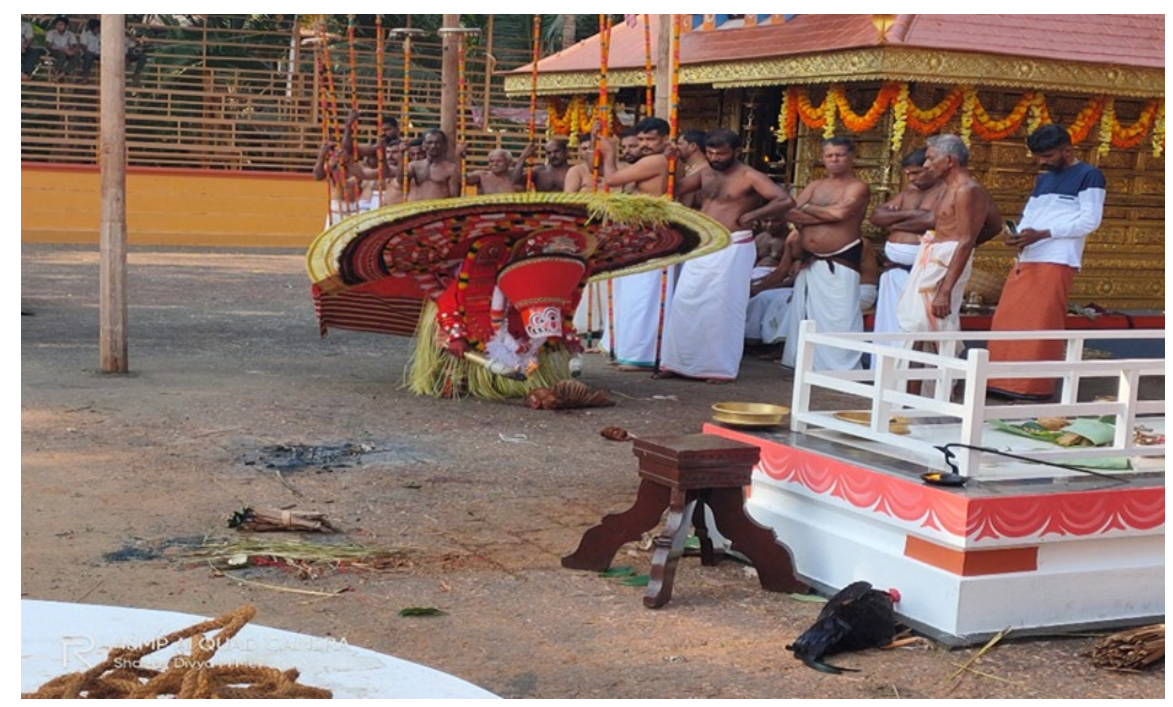

Figure 2 Burning of Hen by Madayil Chamundi Theyyam.

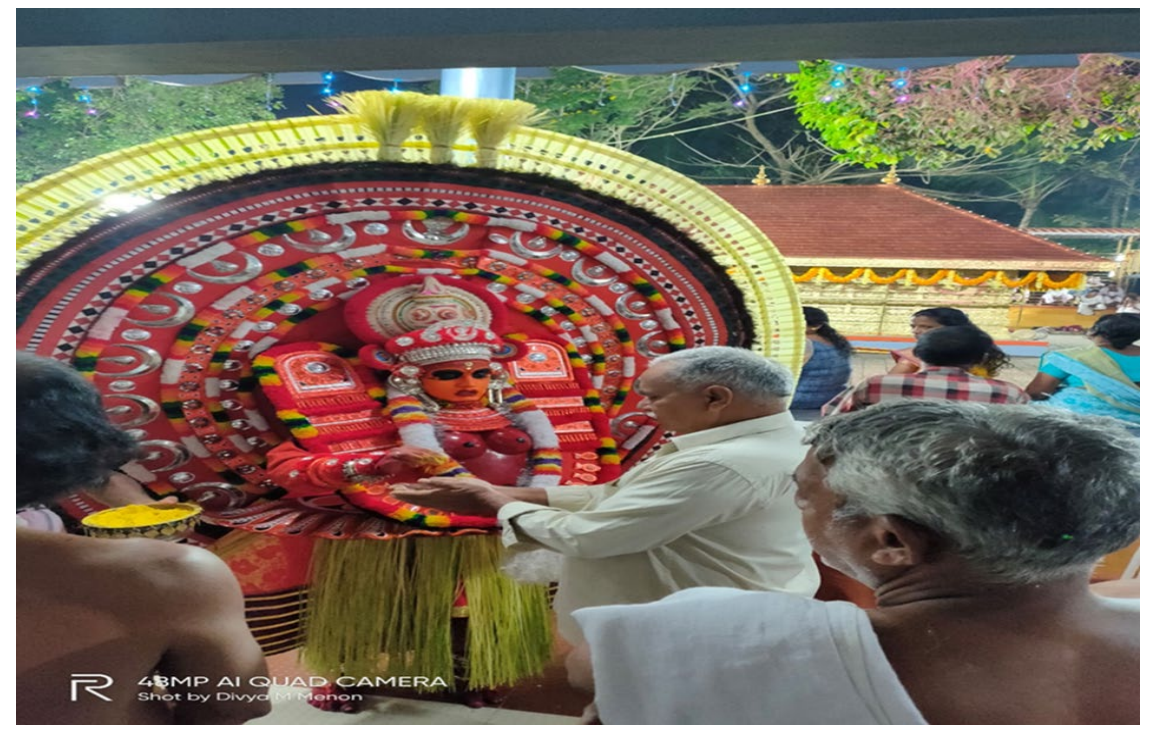

Figure 3 Worshippers are taking blessings from Madayil Chamundi Theyyam.

\section{REFRENCES}

Markose, B. (n. d.). Sacred Grove : Reclaiming a Subaltern Paradigm for Ecological Restoration.

Moi, T. (1989). Sexual/Textual Politics, London : Routledge.

Markose, B. Thomas, L. E. (2018). Rhizomatic Reflections : Discourses on Religion and Theology. Wipf and Stock Publishers, 82-90, 94-96.

Payyanad, R. (1998). Folklorinu Oru Padhanapadhathi, Thrissur : Kerala Sahitya Academy. 
Divya M Menon, and Sreejith D

\section{Spivak, G. C. (2021). The Rani of Sirmur : An Essay in Reading the Archives. History and Theory, JSTOR, 24(3), 247-272. https://doi.org/10.2307/2505169. \\ Upadhyaya, U. P. (1996). Renaissance in Tulu Literature, in Coastal Karnataka, ed. Upadyaya, Uduppi.}

${ }^{1}$ Devakoothu: Theyyam performed by women.

${ }^{2}$ Mundya: playground

${ }^{3}$ Kulam: Clan

${ }^{4}$ Tamizhakam: Region coming under Tamil Nadu in the olden times.

${ }^{5}$ Gramadevathas: Deity worshipped by the entire village.

${ }^{6}$ Kshetradevathas: Deities worshipped in the temple.

${ }^{7}$ Theyyamkeeyal: An occasion where the Theyyam performer wears the headgear.

${ }^{8}$ Theyyakaran: Theyyam performer

${ }^{9}$ Kuladaivom: Deity worshipped by a particular clan.

${ }^{10}$ Daivakkaru: Divine being. 